\title{
Genangan Banjir Pasang Pada Kawasan Pemukiman di Kecamatan Sayung, Kabupaten Demak - Provinsi Jawa Tengah
}

\author{
Petrus Subardjo dan Raden Ario* \\ Jurusan IImu Kelautan, Fakultas Perikanan dan IImu Kelautan, Universitas Diponegoro. \\ JI. Prof. Soedarto, SH. Kampus UNDIP Tembalang, Semarang 50275 \\ email: ario_1960@yahoo.com
}

\begin{abstract}
Abstrak
Wilayah pedesaan di Kecamatan Sayung, Kabupaten Demak merupakan daerah pemukiman yang sering terjadi banjir pasang. Banjir pasang yang menggenangi daerah tersebut karena ketinggian daratan sejajar dan atau lebih rendah dengan muka air laut. Hal ini diduga disebabkan karena terjadinya pasang surut tinggi tertinggi atau HHWL (High Highest Water Level) di wilayah tersebut, sehingga diperlukan suatu tindakan untuk menanggulangi maupun mengurangi dampak yang ditimbukan oleh hal tersebut. Tujuan penelitian ini adalah untuk mengetahui kenaikan pasang surut tinggi tertinggi dari setiap tahunnya dari data nilai HHWL tertinggi setiap bulannya dalam satu tahun. Pengolahan data menggunakan metode admiralty dari tahun 2004-2013 dan tipe pasang surut di Kecamatan Sayung, Kabupaten Demak, serta pemetaan luas area genangan dan luas kawasan pemukiman pada area genangan banjir pasang di Kecamatan Sayung, Kabupaten Demak. Metode yang digunakan dalam penelitian ini adalah metode deskriptif yang bersifat eksploratif yaitu bertujuan untuk menggambarkan keadaan atau status fenomena. Penelitian ini dapat memberikan gambaran tentang situasi dan kondisi secara lokal dan hasilnya tidak dapat digeneralisasikan untuk waktu dan tempat yang berbeda. Selain itu perlu diketahui faktor-faktor penyebab banjir pasang di wilayah tersebut. Data utama yang dibutuhkan adalah data pasang surut, Digital Elevation Model (DEM), titik verifikasi banjir pasang pada kawasan pemukiman, peta tata guna lahan Kabupaten Demak tahun 2008 dan peta rupabumi tahun 2001. Berdasarkan hasil dari penelitian ini diketahui bahwa luas genangan banjir pasang yang terjadi di Kecamatan Sayung, Kabupaten Demak pada tahun 2013 adalah 1.938, 42 ha dan luas kawasan pemukiman pada area genangan sebesar 140,05 ha.Laju kenaikan Pasang surut tinggi tertinggi (HHWL) High highest Water Level dari tahun 2004 sampai tahun 2013 adalah sebesar 13.63 dan nilai HHWL tertinggi yang digunakan untuk membuat genangan banjir pasang dalam penelitian ini adalah bulan desember tahun 2013 sebesar $235.09 \mathrm{~cm}$. Sedangkan Tipe pasang surut yang ada perairan Kecamatan Sayung, Kabupaten Demak adalah campuran condong harian tunggal.
\end{abstract}

Kata kunci : Genangan, Banjir, Pasang, Kawasan Pemukiman, Kecamatan Sayung, Kabupaten Demak

\begin{abstract}
Subdistrict Sayung, Demak is the frequent flooding in residental areas. Flood tides inunndated areas which have a height of land area equal with the sea surface or lower than the sea surface. The areas thatoften Floods are Sriwulan Village, Purwosari Village, Sidogemah Village,Tugu Village, Surodadi Village, Gemulak Village, Bedono Village and Timbul Sloko Village. This happened because high highest water level at that areas, so that the action nasneccesary to overcome or decrease the impact. The purpose of this research was to determine the highest tidalrise in every year from the highest HHWL data values of each month in a year with admiralty data processing method from 2004-2013 as well as in the sub-type tidal Sayung, Demak and inundation mapping area and extensive residental areas to tidal inundation area in the district Sayung, Demak - Central Java Province. Method used
\end{abstract}


in this research is descriptive explorative method that intoonded to describle the state or status of phenomenom. This research can provide an overvieuw of situation and conditions locally and the results may not generalizable to a different time and place. Besides that we need to known the causing factors of flooding in the region the main data we need required tidal flooding data, DEM (Digital Elevation Model), verification point in the settlement area, land use maps Demak in 2008 and 2001 topographical map. Based on the result of this research that widespread inundation flooding that occured in the district Sayung Demak in 2013 is $1.938,42$ ha and extensive of residental areas to the inundation area of 140.05 ha. The rate of the highest tidal rise (HHWL) from 2004 to 2013 amounted 13.63 and the highest value of HHWL used to create tidal inundation in the study was desember 2013 amounted to 235.09 $\mathrm{cm}$. While type of tidal waters that exist in the district Sayung, Demak is a mixture of singlelearning daily.

Keywords : Inundated, Flood Tide, Settlements, Subdistrict Of Sayung, Demak Regency

\section{PENDAHULUAN}

Wilayah pesisir Kecamatan Sayung memiliki berbagai bentuk pemanfaatan lahan, dari banyaknya penggunaan lahan penting mulai dari pemukiman, industri, jalan dan fasilitas umum lainya (BAPEDA Kabupaten Demak, 2007). Salah satu permasalahan daerah pesisir Kecamatan Sayung yaitu banjir pasang, yang diakibatkan karena air laut pasang. Banjir pasang tersebut menggenangi daerah yang lebih rendah dari muka air laut pada saat pasang tertinggi, Daerah pedesaan yang sering terjadi banjir pasang di Kecamatan Sayung adalah Desa Sriwulan, Purwosari, Bedono, Sayung, Timbul Sloko, Sidogemah,Gemulak dan Surodadi (Subardjo, 2004).

Salah satu penyebab utama terjadinya banjir pasang di Kecamatan Sayung adalah ketinggian tanah lebih rendah dibandingkan dengan ketinggian air pada saat terjadi pasang tertinggi muka air laut. Selain itu beberapa area pemukiman di pesisir Kecamatan Sayung jaraknya dekat dengan garis pantai, sehingga pada saat terjadinya pasang tertinggi maka area pemukiman tersebut akan tergenang banjir pasang. Banjir pasang dapat terjadi melalui sungai yang bermuara di laut,dimana pada saat terjadi air laut sedang pasang, maka air laut akan masuk melalui sungai sehingga mengakibatkan air di sungai tersebut akan meluap. Luapan air laut pada saat pasang melalui sungai tersebut akan menggenangi kawasan pemukiman yang berada di sekitarnya dan mengakibatkan penurunan fungsi lahan terutama pada kawasan pemukiman (DKP, 2007).

Penelitian ini penting dilakukan,
karena dapat diketahui beberapa masalah seperti luasan area genangan dan luasan area pemukiman yang terkena dampak banjir pasang.

\section{MATERI DAN METODE}

Materi dalam penelitian terdiri dari beberapa data yang digunakan sebagai acuan untuk menghitung luas genangan banjir pasang dan luas pemukiman pada area genangan banjir pasang, yaitu:

1. Data pasang surut tahun 2004 sampai tahun 2013 dari BMKG Kota Semarang sebagai stasiun pasang surut yang dapat mewakili untuk Kecamatan Sayung, Kabupaten Demak - Provinsi Jawa Tengah,

2. Data Pasang Surut pengukuran lapangan selama 15 hari yaitu pada tanggal 20 Desember 2013 sampai 3 Januari 2014,

3. Peta Rupabumi Indonesia Kabupaten Demak skala 1:25.000 (Bakosurtanal, 2001),

4. Peta Tata Guna Lahan skala 1:25.000 (BAPPEDA Demak, 2008),

5. Data survei lapangan di daerah pemukiman yang tergenang banjir pasang.

Metode dalam penelitian ini merupakan metode deskriptif yang bersifat 
eksploratif. Menurut Arikunto (1993), penelitian dengan metode ini bertujuan untuk menggambarkan keadaan atau status fenomena. Penelitian ini dapat memberikan gambaran tentang situasi dan kondisi secara lokal dan hasilnya tidak dapat digeneralisasikan untuk tempat yang berbeda.

Penelitian bertujuan untuk mengetahui luas area genangan banjir pasang dan luas kawasan pemukiman pada area genangan banjir pasang di Kecamatan Sayung, Kabupaten DemakProvinsi Jawa Tengah, dalam penelitian ini pengolahan data menggunakan softwareE.R Mapper 7.0 dan ArcGIS 9.2. Langkah awal dalam penelitian ini adalah:

1. Pengolahan Peta Rupabumi Indonesia skala 1:25.000 (Bakosurtanal, 2001) dan Peta Tata Guna Lahan Kabupaten Demak Skala 1:25.000 (Bapeda Demak, 2008) yang bertujuan untuk mengetahui batas administrasi dan penggunaan lahan terutama kawasan pemukiman di Kecamatan Sayung, Kabupaten Demak - Provinsi Jawa Tengah.

2. Pengolahan data pasang surut terdapat beberapa metode yang digunakan, yaitu metode analisis data pasang surut, metode penentuan stasiun pasang surut, metode pemasangan palem pasang surut, metode pengambilan data sasang surut dan metode analisis harmonik pasang surut. Semua metode tersebut bertujuan untuk mengetahui nilai pasang muka air laut tertinggi, sebagai masukan data dalam pembuatan peta area genangan banjir pasang.

3. Pengolahan Data Digital Elevation Model (DEM), pengolahan data ini dapat dibuat dengan melakukan interpolasi dari titik titik yang memiliki nilai tinggi atau $Z$ value. Proses interpolasi nilai elevasi untuk setiap piksel dilakukan dengan menggunakan software ER. Mapper 7.0 dengan metode Triangulation All Minimum Curvature menjadi format Raster yang diperoleh dari data topografi RBI format Shp.

4. Pengolahan genangan banjir pasang, pengolahan ini dibuat dari data hasil pengolahan pasang tinggi tertinggi muka air laut tahun 2004-2013 dari BMKG Maritim Kota Semarang, serta data survei pengamatan pasang surut lapangan selama 15 hari yaitu pada tanggal 20 Desember 2013 sampai 3 Januari 2014 dengan menggunakan metode admiralty. Klasifikasi genangan pasang dibuat dengan cara memasukan nilai pasang tinggi tertinggi muka air laut ke data DEM yang telah di overlay dengan Peta Tata Guna Lahan tahun 2008, nilai ketinggian pasang tinggi tertinggi muka air laut yang berada lebih tinggi diatas nilai DEM merupakan daerah yang tergenang, genangan yang dihasilkan kemudian disimpan dalam format raster dalam bentuk vektor, yang berfungsi untuk menghitung luas genangan banjir pasang yang terbentuk dan luas pemukiman pada area genangan banjir pasang.

\section{HASIL DAN PEMBAHASAN}

Data yang dihasilkan diantaranya adalah: hasil analisis harmonik pasang surut, hasil analisis kenaikan pasang surut tinggi tertinggi, analisis spasial genangan banjir pasang, survei lapangan kawasan pemukiman pada area genangan banjir pasang, dan Digital Elevation Model (DEM).

Hasil analisis harmonik pasang surut pada penelitian ini dengan menggunakan metode admiralty akan menghasilkan:

1. Nilai pasang tinggi tertinggi muka air laut atau HHWL (High highest water level) pada tahun 2013 dari pengolahan data pasang surut perekaman tahun 2004 - 2013 yang diperoleh dari BMKG Maritim Kota Semarang yaitu sebesar $235.09 \mathrm{~cm}$, dengan nilai $F$ (Formhzal) sebesar 2.96 dan memiliki tipe pasang surut campuran condong harian tunggal. 
2. Nilai pasang tinggi tertinggi muka air laut atau HHWL (High highest water level) hasil dari pengukuran pasang surut lapangan pada tanggal 20 Desember 2013 sampai 3 januari 2014 sebesar $221.69 \mathrm{~cm}$ dengan nilai formhzal sebesar $2.99 \mathrm{~cm}$ dan memiliki tipe pasang surut campuran condong harian tunggal.

Hasil tipe pasang surut diperkuat oleh Kusuma (2013), bahwa perairan Kabupaten Demak dan sekitarnya memiliki tipe pasang surut campuran condong harian tunggal, hal ini berarti di Perairan Kabupaten Demak terjadi satu kali pasang dan satu kali surut dalam sehari.

Hasil analisis spasial genangan banjir pasang dari penelitian ini didapatkan luas genangan dan luas kawasan pemukiman pada area genangan banjir pasang di Kecamatan Sayung, Kabupaten Demak. Luas genangan yang terjadi di Kecamatan Sayung dari hasil pengolahan data yaitu sebesar 1938.42 ha dan daerah yang paling besar tegenang adalah Desa Sriwulan yang memiliki luas genangan sebesar 621.34 ha sedangkan daerah yang paling kecil tergenang adalah Desa Sidogemah yang memiliki luas genangan sebesar 84,19 ha.

Luas genangan dan daerah yang tergenang akibat banjir pasang di Kecamatan Sayung, Kabupaten Demak Provinsi Jawa Tengah tersaji pada tabel 1 berikut ini :

Tabel 1. Luas Genangan dan Luas Pemukiman Tergenang Banjir Pasang di Kecamatan Sayung, Kabupaten Demak Provinsi Jawa Tengah

\begin{tabular}{clrr}
\hline No & $\begin{array}{c}\text { Wilayah } \\
\text { (Desa) }\end{array}$ & $\begin{array}{c}\text { Luas } \\
\text { Genangan } \\
\text { (Ha) }\end{array}$ & $\begin{array}{c}\text { Luas } \\
\text { Pemukiman } \\
\text { Tergenang } \\
\text { (Ha) }\end{array}$ \\
\hline 1 & Sriwulan & 621.34 & 117.30 \\
2 & Purwosari & 408.23 & 20.82 \\
3 & Sidogemah & 84.19 & 0.50 \\
4 & Surodadi & 305.40 & 24.60 \\
5 & Bedono & 375.40 & 7.36 \\
6 & Timbul Sloko & 143.86 & 1.43 \\
\hline & Total & 1938.42 & 140.05 \\
\hline
\end{tabular}

Daerah genangan banjir pasang, selain didapatkan luas genangan, didalam penelitian ini didapatkan juga luas kawasan pemukiman dikawasan yang tergenang banjir pasang di Kecamatan Sayung ,Kabupaten Demak - Provinsi Jawa Tengah. Luas kawasan pemukiman di kawasan yang tergenang banjir pasang di Kecamatan Sayung - Kabupaten Demak sebesar 172,01 ha. Daerah kawasan pemukiman yang paling besar tergenang adalah Desa Sriwulan,yang memiliki luas genangan sebesar 117.30 ha sedangkan Desa Sidogemah adalah daerah dimana kawasan pemukimanya yang terkecil tergenang banjir pasang (Tabel 1).

Terkait dengan analisis spasial genangan banjir pasang tersebut, menurut Subardjo (2004), area genangan banjir pasang pada saat air laut mengalami pasang tertinggi akan meningkat dan meluas ke darataan sesuai dengan elevasi muka tanah atau morfologi dan distribusinya akan menyesuaikan. Unsur morfologi daratan pantai yang mempengaruhi distribusi genangan banjir pasang tersebut antara lain adalah kemiringan lereng, panjang lereng pantai dan bentuk lereng serta letaknya atau jaraknya dengan garis pantai serta saluran dari limpasan air permukaan. Menurunnya fungsi lahan akibat dari tergenang oleh air laut pada saat pasang naik berdampak langsung pada masyarakat, seperti menurunnya tingkat kesehatan, menurunnya perekonomian setempat akibat gangguan transportasi dan produktifitas. Kondisi tersebut telah berlangsung di Pantai Sayung selama beberapa tahun sejak 1998 dan sampai saat ini belum tertangani secara terpadu.

Survei lapangan pada kawasan pemukiman di area genangan banjir pasang di Kecamatan Sayung, Kabupaten Demak - Provinsi Jawa Tengah dilakukan pada 10 titik sebaran, survei tersebut menggunakan Global Positioning System (GPS), dimana daerah yang tidak terjadi genangan terjadi pada 1 titik survei yaitu berada dititik 5 yang memiliki koordinat (x)110.491 dan (y)-6.9436, sehingga kesalahan relatif atau mean relative error (MRE) dari 10 titik survei lapangan memiliki nilai MRE sebesar 11,11\%. 


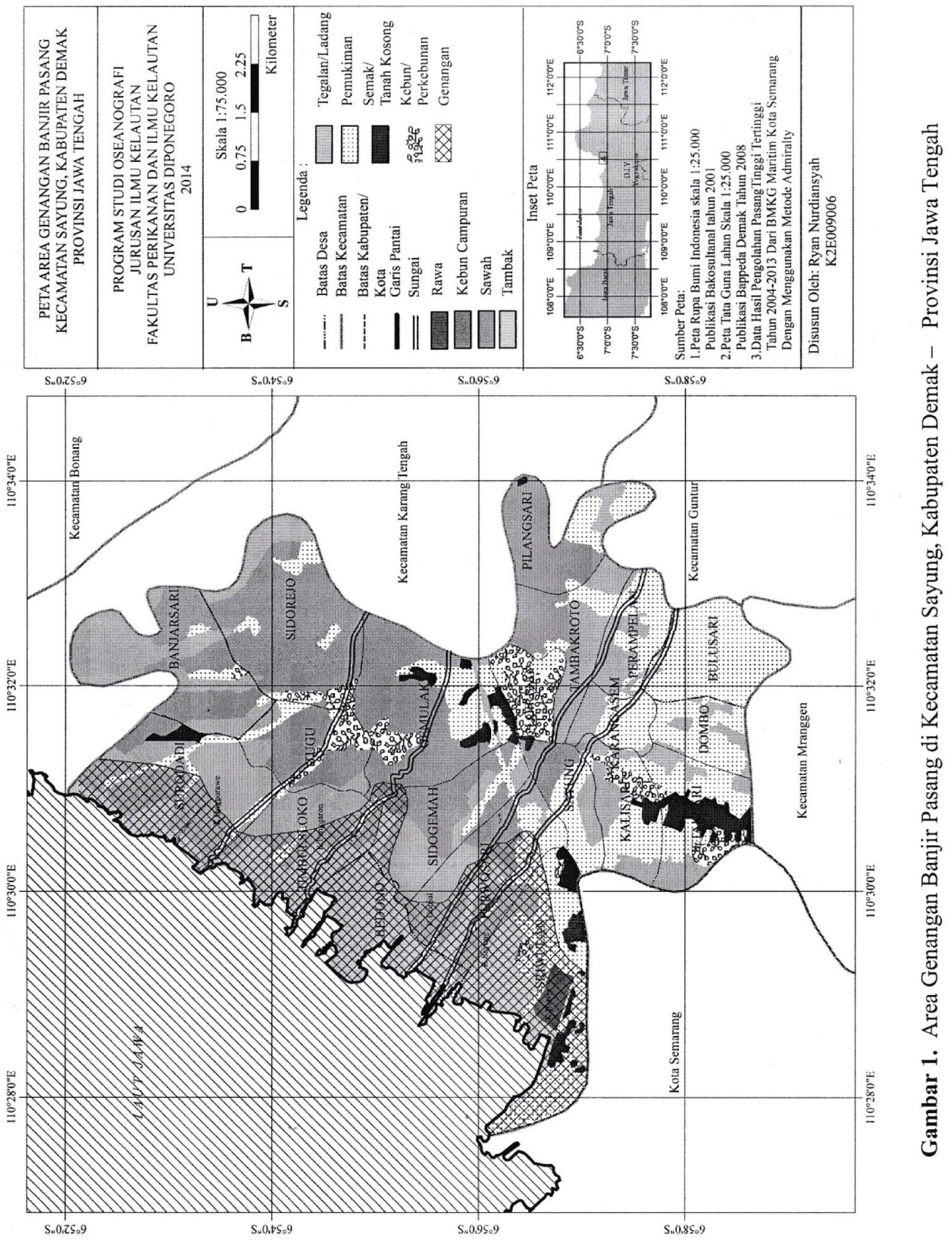


Digital Elevation Model (DEM) Kecamatan Sayung dibuat dengan dengan melakukan interpolasi dari titik titik yang memiliki nilai tinggi atau $Z$ value yang memiliki nilai elevasi berbeda-beda. klasifikasi Elevasi permukaan tanah dapat dilihat pada tabel 2 berikut ini:

Tabel 2. Elevasi Permukaan Tanah di Kecamatan Sayung, Kabupaten Demak, Provinsi Jawa Tengah.

\begin{tabular}{lll}
\hline No & Elevasi Tanah & \multicolumn{1}{c}{ Nama Daerah } \\
\hline 1 & $0-2$ meter & Desa Bedono \\
2 & & Desa Perampelan \\
3 & & Desa Karangasem \\
4 & & Desa Loireng \\
5 & $1-3$ meter & Desa Sidorejo \\
6 & & Desa Tambakroto \\
7 & & Desa Jetaksari \\
8 & & Desa Sayung \\
9 & & Desa Sriwulan \\
10 & & Desa Kalisari \\
11 & & Desa Dombo \\
12 & & Desa Surodadi \\
13 & & Desa Timbul Sloko \\
14 & & Desa Purwosari \\
15 & & Desa Bulusari \\
16 & & Desa Sidogemah \\
17 & & Desa Banjarsari \\
18 & & Desa Gemulak \\
19 & $2-3$ meter & Desa Tugu \\
\hline
\end{tabular}

Menurut Subardjo (2004) Wilayah pesisir Sayung merupakan dataran rendah dengan topografi relatif datar, kurang dari $2 \%$, elevasi $0-5$ meter di atas permukaan air laut. Keadaan yang akan terjadi adalah timbulnya genangan air rob yang berasal dari masuknya air laut ke daratan karena fluktuasi pasang air laut.

\section{KESIMPULAN}

Berdasarkan hasil penelitian ini, dapat disimpulkan bahwa luas genangan banjir pasang yang terjadi di Kecamatan Sayung, Kabupaten Demak - Provinsi Jawa Tengah pada tahun 2013 sebesar 1938.42 ha dan luas kawasan pemukiman yang tergenang akibat banjir pasang di Kecamatan Sayung, Kabupaten Demak Provinsi Jawa Tengah sebesar $140.05 \mathrm{Ha}$.

\section{UCAPAN TERIMAKASIH}

Penulis menyampaikan terima kasih kepada Ryan Nurdiansyah dan semua pihak yang telah membantu memberikan pengarahan dan petunjuk, serta instansi yang telah memberikan bantuan dan fasilitas dalam penelitian ini.

\section{DAFTAR PUSTAKA}

BAPPEDA. 2000. Profil Wilayah Pantai dan Laut Kota Semarang. BAPPEDA Semarang.

BAPPEDA. 2007. Profil Wilayah Pantai dan Laut Kota Demak. BAPPEDA Demak.

BPS Demak. 2013. Jumlah Penduduk Kab Demak Tahun 2013 . Biro Pusat Statistik Demak.

DKP. 2007. Pedoman Mitigasi Bencana Alam di Wilayah Pesisir dan PulauPulau Kecil. Jakarta $64 \mathrm{hlm}$.

Kusuma, A. 2013. Identifikasi Daerah Rawan Rob Untuk Evaluasi Tata Ruang Pemukiman di Kabupaten Demak, Jawa Tengah. PS IImu Kelautan, FPIK UNDIP, Semarang

Subardjo, P. 2004. Studi Morfologi Guna Pemetaan Rob di Pesisir Sayung, Kabupaten Demak, Jawa Tengah. PS IImU Kelautan, FPIK Universitas Diponegoro. Semarang. 